J. Amer. Soc. Hort. Sci. 120(2):325-328. 1995.

\title{
Yield and Fruit Size Stability Differs among Bell Pepper Cultivars
}

\author{
Peter J. Stoffella \\ Agricultural Research and Education Center, IFAS, University of Florida, Fort Pierce, FL 34945
}

Salvador J. Locascio

Horticultural Sciences Department, IFAS, University of Florida, Gainesville, FL 32611

Teresa K. Howe

Gulf Coast Research and Education Center, IFAS, University of Florida, Bradenton, FL 34203

Steve M. Olson

North Florida Research and Education Center, IFAS, University of Florida, Quincy, FL 32351

Kenneth D. Shuler

Palm Beach County Cooperative Extension Service, West Palm Beach, FL 33415

\author{
Charles S. Vavrina \\ Southwest Florida Research and Education Center, IFAS, University of Florida, Immokalee, FL 33934
}

Additional index words. Capsicum annuum, cultivar $\times$ environment interactions, adaptability

\begin{abstract}
Bell pepper (Capsicum annuum L.) cultivars were grown in nine Florida environments to evaluate phenotypic stability of marketable fruit yield (t-ha- ${ }^{\circ}$ ) and mean fruit size (g/fruit). A stable cultivar excelled for a particular trait when grown in either favorable or unfavorable environments. A stable cultivar for a given trait was defined as one with an individual mean greater than the grand mean (mean of all cultivars) $(x>X)$, a regression coefficient $\left(b_{1}\right) \leq 1$ (individual genotypic mean regressed against environmental means), nonsignificant deviation mean squares from regression ( $\left.\mathrm{S}^{2} \mathrm{~d}\right)$, coefficient of linear determination $\left(R^{2}\right)>0.50$, and coefficient of variation (cv) < the pooled cv. 'Ssupersweet 860', 'Whopper Improved', and 'Ranger' were stable for mean marketable fruit weights and fruit size, and 'Ssupersweet 860' and 'Whopper Improved' were stable for mean fruit size. Bell pepper cultivars were differentiated for phenotypic stability of yield and fruit size or adaptability to diverse environments. Therefore, through stability analyses, bell pepper plant breeders can identify cultivars or select advanced breeding lines that express adaptability for fruit yields or size to diverse environmental conditions or cultural practices.
\end{abstract}

Stability of yield or fruit quality traits is measured to determine adaptation of specific cultivars or advanced breeding lines to an array of production environments. Environments may vary in cultural or management practices and climatic or edaphic conditions. Plant breeders, through stability analyses, can determine if existing cultivars or selections are adapted to favorable, unfavorable, or both environmental conditions.

Yield stability has been evaluated on solanaceae crops including potato (Solanum tuberosum L.) (Dhiman, et al., 1986; Lynch and Kozub, 1988; Tai, 1971), tomato (Lycoperscion esculentum Mill.) (Berry, et al., 1988; Cuartero and Cubero, 1982; Izquierdo, et al., 1980; Ortiz and Izquierdo, 1994; Poysa, et al., 1986; Stoffella, et al, 1984), and sweet pepper (Capsicum annuum L.) (Carillo, et al., 1991).

Phenotypic yield stability of a particular cultivar can be assessed by use of the regression coefficient $\left(b_{1}\right)$ derived from regression models consisting of individual cultivar means for a particular trait as the dependent variable and environmental means (mean of all cultivars within an environment) as the independent variable (Finlay and Wilkinson, 1963) and the deviation from linear regression mean squares $\left(S^{2} d\right)$ (Eberhart and Russell, 1966). Other stability parameters have been developed and have been

Received for publication 1 Aug. 1994. Accepted for publication 7 Nov. 1994. Florida Agricultural Experiment Station Journal Series No. R-03971. We gratefully acknowledge the financial support provided by the Florida Bell Pepper Growers' Exchange. The cost of publishing this paper was defrayed in part by the payment of page charges. Under postal regulations, this paper therefore must be hereby marked advertisement solely to indicate this fact. reviewed by Becker and Leon (1988) and Lin et al. (1986).

Bell peppers were grown on $>8000$ ha and were valued at $\$ 179$ million during the 1992-1993 crop year in Florida (Florida Agricultural Statistics, 1994). Bell peppers are grown under diverse cultural practices, soil types, and climates in Florida (Hochmuth, 1988). The purpose of this investigation was to assess fruit yield and size stability of several bell pepper cultivars grown in differing Florida environments.

\section{Material and Methods}

Cultivar performance trial. 'Jupiter', 'Early Calwonder', 'Ssupersweet 860', 'Orobelle', 'Memphis', 'Bell Captain', 'Galaxy', 'Gator Belle', 'Whopper Improved', 'Ranger', 'Rebell', 'Capistrano', 'Boynton Bell', and 'King Arthur' bell peppers were transplanted at seven locations in Florida during 199 1. Each trial utilized the characteristic raised, full-bed polyethylene mulch cultural system (Hochmuth, 1988). Production season, soil type, fertilization rate, planting arrangement, plant population, and number of harvests are presented in Table 1. A randomized complete-block experimental design with each cultivar replicated four times was used for each experiment.

Fruit were harvested from each plot, graded into marketable and cull, and the marketable fruit were counted and weighed. For each plot, marketable fruit number and weight for all harvests were combined to obtain seasonal mean fruit size (g/fruit) and marketable yields $\left(\mathrm{t} \cdot \mathrm{ha}^{-1}\right)$.

Statistical analyses. Combined analyses of variance (ANOVA) 


\begin{tabular}{|c|c|c|c|c|c|c|c|c|c|c|}
\hline \multirow[b]{4}{*}{ Location } & & & \multicolumn{3}{|c|}{ Arrangement } & & & & \multirow{4}{*}{$\begin{array}{c}\text { Plant } \\
\text { population } \\
\text { (plants/ha) }\end{array}$} & \multirow{4}{*}{$\begin{array}{c}\text { Harvest' } \\
\text { (no.) }\end{array}$} \\
\hline & & & & & \multirow{3}{*}{$\begin{array}{l}\text { Rows/bed } \\
\text { (no.) }\end{array}$} & \multirow{2}{*}{\multicolumn{3}{|c|}{$\begin{array}{l}\text { Fertilizer } \\
\text { applied } \\
\left(\mathrm{kg} \cdot \mathrm{ha}^{-1}\right)\end{array}$}} & & \\
\hline & \multicolumn{2}{|c|}{ Environment } & \multirow{2}{*}{$\begin{array}{c}\text { Beds } \\
(\mathrm{m})\end{array}$} & \multirow{2}{*}{$\begin{array}{c}\text { Plants } \\
(\mathrm{m})\end{array}$} & & & & & & \\
\hline & Season & Soil type & & & & $\mathrm{N}$ & $\mathrm{P}$ & $\mathrm{K}$ & & \\
\hline Boyoton Beach & Fall & Oldsmar sand & 1.82 & 0.20 & 2 & 336 & 72 & 491 & 53,797 & 3 \\
\hline Bradenton & Spring & Eau Gallie fine sand & 1.52 & 0.27 & 2 & 316 & 51 & 364 & 48,027 & 3 \\
\hline & Fall & Eau Gallie fine sand & 1.52 & 0.24 & 2 & 316 & 51 & 364 & 48,027 & 4 \\
\hline Ft. Pierce & Spring & Oldsmar fine sand & 2.13 & 0.25 & 2 & 145 & 129 & 263 & 36,906 & 3 \\
\hline & Fall & Oldsmar fine sand & 2.13 & 0.25 & 2 & 145 & 129 & 263 & 36,906 & 4 \\
\hline Gainesville & Spring & Arrendondo fine sand & 1.22 & 0.30 & 1 & 170 & 10 & 160 & 27,322 & 2 \\
\hline Immokalee & Fall & Immokalee fine sand & 1.83 & 0.25 & 2 & 224 & 90 & 280 & 43,055 & 3 \\
\hline Loxahatchee & Spring & Riveera sand & 1.82 & 0.25 & 2 & 364 & 95 & 459 & 43,631 & 4 \\
\hline Quincy & Spring & Dothan loamy fine sand & 1.83 & 0.30 & 2 & 218 & 30 & 181 & 35,860 & 3 \\
\hline
\end{tabular}

'Harvest number indicates total number of harvests during the season.

were performed for marketable fruit yield and mean fruit size. For the combined analyses, a split-block experimental design was used with environments as the main block and cultivars as the splitblock. Cultivar $x$ environment interactions were significant for marketable fruit yield and mean fruit size (Table 2), therefore, subsequent stability analyses were performed.

Regression coefficient $\left(b_{1}\right)$ (Finlay and Wilkinson, 1963) was a

Table 2. Mean squares from combined analysis of variance for marketable hell pepper fruit yield and mean fruit size.

\begin{tabular}{lccc}
\hline & & \multicolumn{2}{c}{ Mean squares } \\
\cline { 3 - 4 } $\begin{array}{l}\text { Source of } \\
\text { variation }\end{array}$ & df & $\begin{array}{c}\text { Fruit yield } \\
\left(\mathrm{t} \cdot \mathrm{ha}^{-1}\right)\end{array}$ & $\begin{array}{c}\text { Fruit size } \\
(\mathrm{g} / \mathrm{fruit})\end{array}$ \\
\hline Environment (E) & 8 & $6228^{* *}$ & $62,846^{* *}$ \\
Replication/E & 27 & 76 & 232 \\
Cultivar (C) & 13 & $141^{* *}$ & $2398^{* *}$ \\
$\mathrm{C} \times \mathrm{E}$ & 104 & $51^{* *}$ & $308^{* *}$ \\
Experimental error & 351 & 16 & 118 \\
**Significant at $P=0.01$ & & &
\end{tabular}

**Significant at $P=0.01$. stability parameter calculated for each cultivar from the equation model

$\mathrm{A}=\mathrm{b}_{\mathrm{o}}+\mathrm{b}_{1} \mathrm{x}_{1}$

where $\mathrm{A}$ is the mean of an individual cultivar for a given trait, $\mathrm{b}_{\mathrm{o}}$ is the $\mathrm{Y}$-axis intercept, $\mathrm{b}_{1}$ is the linear regression coefficient or slope, and $\mathrm{x}_{1}$ is the environmental mean (mean from all cultivars within an environment) for a given trait. Attest was used to test the hypothesis:

$\mathrm{H}_{\mathrm{o}}: \mathrm{b}_{1}=1$

The deviation from linear regression mean squares $\left(\mathrm{S}^{2} \mathrm{~d}\right)$ (Eberhart and Russell, 1966) was the second stability parameter. A $\mathrm{F}$ test ( $\mathrm{S}^{2} \mathrm{~d}$ was tested against the pooled error mean square) was used to test if $S^{2} d$ was significant for each cultivar.

The coefficient of linear determination $\left(R^{2}\right)$ was calculated for each linear regression model and served as the third stability parameter (Gull et al., 1989; Stoffella et al., 1984). Genotypes with $R^{2}$ values $>50 \%$ were considered stable since $50 \%$ or more of the ANOVA sum of squares or variation would be attributed to linear regression, whereby $<50 \%$ of the total variation would be unex-

Table 3. Stability parameters for marketable fruit yield of 14 bell pepper cultivars.

\begin{tabular}{|c|c|c|c|c|c|}
\hline Cultivar & $\begin{array}{c}\text { Mean } \\
\text { fruit } \\
\text { yield } \\
\left(\mathrm{t} \cdot \mathrm{ha} \mathrm{a}^{-1}\right)\end{array}$ & $\begin{array}{c}\text { Regression } \\
\text { coefficient } \\
\left(b_{1}\right)\end{array}$ & $\begin{array}{l}\text { Deviations } \\
\text { mean square } \\
\text { from regression } \\
\left(\mathrm{S}^{2} \mathrm{~d}\right)\end{array}$ & $\begin{array}{c}\text { Coefficient } \\
\text { of linear } \\
\text { determination } \\
\left(R^{2}\right)\end{array}$ & $\begin{array}{l}\text { Coefficient } \\
\text { of } \\
\text { variation } \\
\text { (cv) }\end{array}$ \\
\hline Jupiter & 21.1 & 1.06 & 16.4 & 0.84 & 22.7 \\
\hline Early Calwonder & 19.0 & 0.98 & $38.5^{*}$ & 0.83 & 23.8 \\
\hline Ssupersweet 860 & 24.3 & $0.84^{*}$ & 5.7 & 0.81 & 17.2 \\
\hline Orobelle & 22.4 & 0.96 & 52.7 & 0.78 & 22.4 \\
\hline Memphis & 21.7 & 1.10 & 40.4 & 0.85 & 22.1 \\
\hline Bell Captain & 21.5 & 1.02 & 23.4 & 0.79 & 25.0 \\
\hline Galaxy & 23.1 & 1.05 & 49.7 & 0.77 & 25.5 \\
\hline Gator Belle & 25.2 & 1.17 & 55.8 & 0.82 & 22.0 \\
\hline Whopper Improved & 23.3 & 1.00 & 24.8 & 0.83 & 19.8 \\
\hline Rebell & 22.6 & 1.02 & 34.6 & 0.82 & 21.6 \\
\hline Ranger & 22.9 & $0.77 * *$ & 12.6 & ().82 & 16.1 \\
\hline Capistrano & 21.5 & 1.01 & $43.0^{*}$ & 0.84 & 20.8 \\
\hline Boynton Bell & 27.2 & $1.27^{*}$ & $19.0 * *$ & 0.76 & 27.2 \\
\hline King Arthur & 23.7 & $0.72 * *$ & $27.1^{*}$ & 0.81 & 15.2 \\
\hline $\mathrm{X}$ & 22.8 & 1.0 & & & 21.5 \\
\hline
\end{tabular}

*,**Significant at $P=0.05$ or 0.01 . Indicates that $\mathrm{b}_{1}$ is significantly different from unity at $P=0.05$ or 0.01 . 
Table 4. Stability parameters for mean fruit size of 14 bell pepper cultivars.

\begin{tabular}{|c|c|c|c|c|c|}
\hline Cultivar & $\begin{array}{c}\text { Mean } \\
\text { fruit } \\
\text { size } \\
\text { (g/fruit) }\end{array}$ & $\begin{array}{l}\text { Regression } \\
\text { coefficient } \\
\left(b_{1}\right)\end{array}$ & $\begin{array}{l}\text { Deviations } \\
\text { mean square } \\
\text { from regression } \\
\left(S^{2} d\right)\end{array}$ & $\begin{array}{c}\text { Coefficient } \\
\text { of linear } \\
\text { determination } \\
\left(R^{2}\right)\end{array}$ & $\begin{array}{l}\text { Coefficient } \\
\text { of linear } \\
\text { determination } \\
\text { (cv) }\end{array}$ \\
\hline Jupiter & 146 & 1.05 & 318 & 0.82 & 11.1 \\
\hline Early Calwonder & 117 & 0.89 & 108 & 0.88 & 8.5 \\
\hline Supersweet 860 & 144 & 1.01 & 147 & 0.88 & 8.4 \\
\hline Orobelle & 136 & 1.03 & $309^{*}$ & 0.88 & 9.1 \\
\hline Memphis & 141 & 1.11 & 91 & 0.95 & 6.1 \\
\hline Bell Captain & 142 & 0.93 & $327 * *$ & 0.87 & 8.1 \\
\hline Galaxy & 144 & 1.01 & $310^{* *}$ & 0.89 & 7.9 \\
\hline Gator Belle & 137 & 1.03 & 351 & 0.87 & 9.2 \\
\hline Whopper Improved & 147 & 1.06 & 163 & 0.92 & 7.1 \\
\hline Rebell & 131 & 1.05 & $415^{* *}$ & 0.87 & 10.1 \\
\hline Ranger & 131 & $0.83^{* *}$ & $253^{* *}$ & 0.87 & 7.9 \\
\hline Capistrano & 149 & 0.97 & $445^{* *}$ & 0.86 & 8.6 \\
\hline Boynton Bell & 152 & 0.99 & 203 & 0.80 & 10.5 \\
\hline King Arthur & 154 & 1.05 & $779^{* *}$ & 0.90 & 11.1 \\
\hline $\mathrm{X}$ & 142 & 1.0 & & & 8.8 \\
\hline
\end{tabular}

*** Significant at $\mathrm{P}=0.05$ or 0.01 . Indicates that $\mathrm{b}_{1}$ is significantly different from unity at $P=0.01$.

plained or experimental error.

Coefficient of variation (cv) (Francis and Kannenberg, 1978) was calculated as

$\mathrm{cv}=(\mathrm{s} / \mathrm{x}) \times 100$

where $\mathrm{cv}$ is the coefficient of variation, $\mathrm{S}$ is the standard deviation and $\mathrm{x}$ is the mean of a given trait for a specific cultivar.

Stability definition. A cultivar was considered to possess stability (adaptability to favorable and unfavorable environment) for a given trait if the individual cultivar mean was greater than the grand mean $(x>X), b_{1} \leq 1$, deviations from $S^{2} d$ was nonsignificant, $R^{2}>0.50$, and the cv was less than the pooled mean cv.

\section{Results and Discussion}

Bell pepper yields and fruit size were significantly affected by the environment in which they were grown (Table 2). Mean marketable bell pepper fruit yields of the 14 cultivars grown at the nine environments were quite variable and ranged from 11.9 to $44.7 \mathrm{t} \cdot \mathrm{ha}^{-1}$ (Data not shown). This suggested that the cultivar evaluation sites covered a diverse range of favorable and unfavorable environments for production of bell pepper in 1991. Mean fruit sizes (g/fruit) were also variable and ranged from 71 to 185 at the nine environments (Data not shown).

Marketable fruit yield and fruit size were significantly influenced by cultivar (Table 2). Mean fruit yields for the 14 cultivars ranged from 19.0 to $27.2 \mathrm{t} \cdot \mathrm{ha}^{-1}$ (Table 3 ) and mean fruit sizes ranged from 127 to $154 \mathrm{~g} /$ fruit (Table 4). However, environment and cultivar significantly interacted in their effects on marketable fruit yield and mean fruit size (Table 2). Since cultivar and environment significantly interacted, stability analyses could be performed.

Based on our stability definition (material and methods), ' Ssupersweet 860', 'Whopper Improved', and 'Ranger' had phenotypic stability for marketable fruit yield. Using $b_{1}, S^{2} d$, and comparison of cultivar means (x vs. X), Carillo et al. (1991) reported stability differences among sweet pepper cultivars for yield, fruit number per plant, fruit size (g/fruit), and plant height.

The parameter $R^{2}$ was not useful in our study as a stability index for marketable fruit yield, since each model had $R^{2}>0.50$. Stoffella et al. (1988) also reported $R^{2}>0.50$ for each tomato cultivar model evaluated for marketable fruit yield stability, indicating the ineffectiveness of $R^{2}$ as a stability parameter. However, Gull et al. (1989) reported $R^{2}<0.50$ when measuring stability of percent citric acid, percent soluble solid, ascorbic acid, color $\mathrm{a} / \mathrm{b}$, percent $\mathrm{N}$, and percent dry weight in several cultivars of fresh marketable tomato fruit.

As previously defined, 'Ssupersweet 860' and 'Whopper Improved' were stable for mean fruit size (Table 4). As with marketable fruit yields, $R^{2}$ for fruit size model was not a useful stability parameter, since each cultivar had $R^{2}>0.50$.

The results indicated that bell pepper cultivars could be differentiated for stability of marketable fruit yield and mean fruit size by using our stability definition. 'Ssupersweet 860' and' Whopper Improved' were considered stable for marketable fruit yield and mean fruit size and 'Ranger' was considered stable for mean fruit size. The $\mathrm{S}^{2} \mathrm{~d}$ was not an effective parameter to screen for phenotype stability of bell pepper fruit yield or size.

Plant breeders should consider stability analyses as a method of identifying bell pepper cultivars or selecting advanced breeding lines for adaptability to diverse environmental production areas.

\section{Literature Cited}

Becker, H.C. and J. Leon. 1988. Stability analysis in plant breeding. Plant Breeding 101:1-23.

Berry, S. Z., M. Rafique Uddin, W. A. Gould, A.D. Bisges, and G.D. Dryer. 1988. Stability in fruit yield, soluble solids, and citric acid of eight machine-harvested processing tomato cultivars in northern Ohio. J. Amer. Sot. Hort. Sci. 113:604-608.

Carrillo, N. C., F.A. Vallejo, and E.I. Estrada. 1991. Phenotypic adaptability and stability of four lines and six hybrids of sweet pepper, Capsicum annuum L. Acta Agron. 41(1-4):21-36.

Cuartero, J. and J.I. Cubero. 1982. Cultivar-environment interactions in tomato. Theoretical Applied Genet. 61:273-277.

Eberhart, S.A. and W.A. Russell. 1966. Stability parameters for comparing varieties. Crop Sci. 6:36-40.

Dhiman, K, R., B.L. Barua, and H.S. Gupta. 1986. Phenotypic stability analyses of tuber yield in potato. Crop Improv. 13:226-227.

Finlay, K.W. and G.N. Wilkinson. 1963. The analysis of adaptation in plant-breeding programme. Austral. J. Agr, Res. 14:742-754.

Florida Agricultural Statistic Service. 1994. Florida Agricultural Statistics, vegetable summary 1992- 1993. Florida Agri. Stat. Serv., Orlando. 
Francis, T.R. and L.W. Kannenberg. 1978. Yield stability studies in shortseason maize. I. A descriptive method for grouping cultivars. Can. J. Plant Sci. 58:1029-1034.

Gull, D.D., P.J. Stoffella, S.J. Locascio, S.M. Olson, H.H. Bryan, P.H. Everett, T.K. Howe, and J.W. Scott. 1989. Stability differences among fresh-market tomatoes. II. Fruit quality. J. Amer. Soc. Hort. Sci. 111:950954.

Hochmuth, G.J. (ed). 1988. Pepper production guide for Florida. Florida Coop. Ext. Serv. Circ. 102 E.

Izquierdo, J.A., C.R. Maeso, and J. Villamil. 1980. Stability in the production of eight cultivars of canning tomatoes. Investigaciones Agron. 1:47-51.

Lin, C.S., M.R. Binns, and L.P. Lefkovitch. 1986. Stability analysis: Where do we stand? Crop Sci. 26:894-900.
Lynch, D.R. and G.C. Kozub. 1988. An analysis of the response of nine potato cultivars to five prairie environments. Can. J. Plant Sci. 68: 12191228.

Ortiz, R. and J. Izquierdo. 1994. Yield stability differences among tomato genotypes grown in Latin America and the Caribbean. Hort Sci. 29: 11751177.

Poysa, V.M., R. Garton, W.H. Courtney, J.G. Metcalf, and J. Muehmer. 1986. Cultivar-environment interactions in processing tomatoes in Ontario. J. Amer. Soc. Hort. Sci. 111:293-297.

Stoffella,P.J., H.H. Bryan,T.K. Howe, J.S. Scott, S.L. Locascio, and S.M. Olson. 1984. Stability differences among fresh market tomato cultivars. I. Fruit yields. J. Amer. Soc. Hort. Sci. 109:615-618.

Tai, G.C.C. 1971. Genotypic stability analysis and its application to potato regional trials. Crop Sci. 11: 184-190. 